Iranian Quarterly Journal of Breast Disease 2018; 11(3):44.

\title{
Effect of Six Weeks of Endurance Training on Tumor Volume and Muscle Myostatin Levels in Female Mice with Breast Cancer: Implications for Cachexia
}

Hasani F: M.A student of department of physical education and sport sciences, science and research branch, Islamic Azad University, Tehran, Iran

Gholami M: Department of physical education and sport sciences, science and research branch, Islamic Azad University, Tehran, Iran

Ghazalian F: Department of physical education and sport sciences, science and research branch, Islamic Azad University, Tehran, Iran

Corresponding Author: Mandana Gholami, m.gholami@srbiau.ac.ir

\begin{abstract}
Introduction: Cachexia is one of the main cancer-related complications. Changes in levels of cachexia-related factors such as myostatin play an important role in accelerating or muscle wasting. The aim of present study was to investigate the effect of six weeks of endurance training on myostatin levels in female mice with breast cancer.

Methods: Twenty-four female BALB/c mice, aged 6-8 weeks, were assigned to three groups of 8 mice each: a healthy control, tumor control, and an endurance training + tumor group. The endurance training program was performed for six weeks, five sessions per week, at $14-18 \mathrm{~m} / \mathrm{min}$ on a rodent treadmill. Forty-eight hours after the last exercise session, gastrocnemius muscle tissue was removed and myostatin levels were determined with ELISA method. Tumor volume was measured with a digital caliper.
\end{abstract}

Results: Results indicated significant decreases in myostatin levels in the training + tumor group when compared with the tumor control group $(\mathrm{p}<0.001)$. However, myostatin levels in the control group were significantly low compared with the tumor control and training + tumor groups $(p<0.05)$. Moreover, significant increases in the gastrocnemius muscle weight $(p=0.015)$ and decreases in tumor volume $(\mathrm{p}<0.001)$ were observed in the training + tumor group.

Conclusion: It seems that decreased myostatin levels due to endurance training have an important role in the prevention of muscle wasting. According to our findings, endurance training, in addition to suppressing tumor growth, can be considered an effective strategy for combating muscle loss in cancer patients.

Keywords: Cachexia, Tumor, Myostatin, Endurance Training 


\section{تاثير شش هفته تمرين استقامتى بر حجم تومور و سطوح ميوستاتين در بافت عضلانى موشهاى

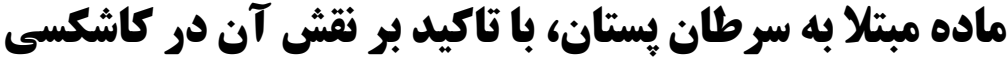

فاطمه حسنى: دانشجوى كارشناسى ارشد، كروه تربيت بدنى و علوم ورزشى، واحد علوم و تحقيقات، دانشكاه آزاد اسلامى، تهران، ايران

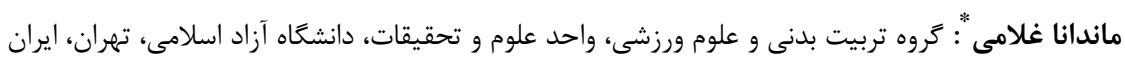

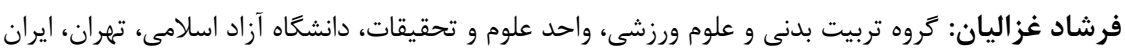

\section{جكيده}

مقدمه: كاشكسى يكى از عوارض اصلى مرتبط با سرطان است. تغيير در سطوح عوامل مرتبط با كاشكسى از قبيل ميوستاتين

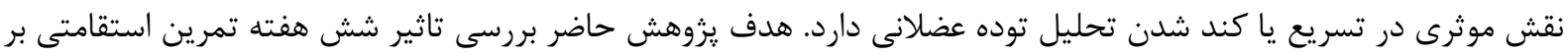

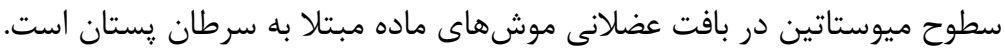
روش بررسى: بدين منظور FF سر موش ماده Balb/c شش تا هشت هفتهاى در سه گروه 1 تايى شامل گروههاى كنترل

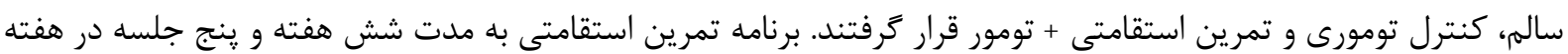

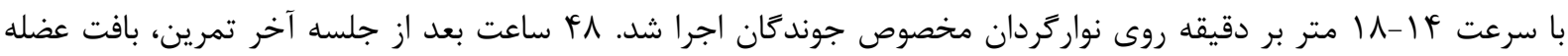

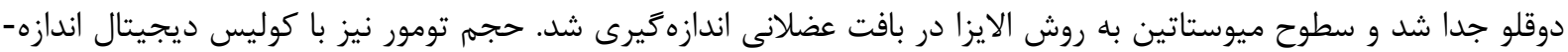
كيرى شد. يافتهها: نتايج كاهش معنادار سطوح ميوستاتين را در بافت عضلانى كروه تمرين+تومور در مقايسه با كروه كنترل تومورى

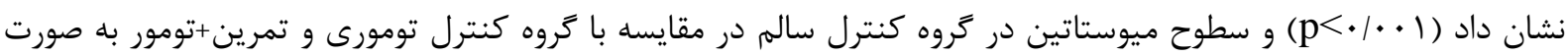

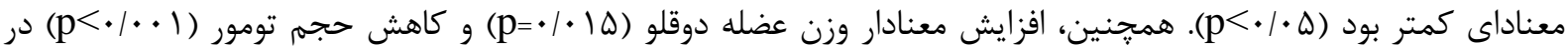
كروه تمرين+تومور مشاهده شد.

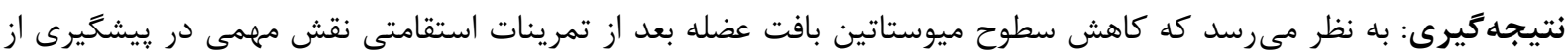

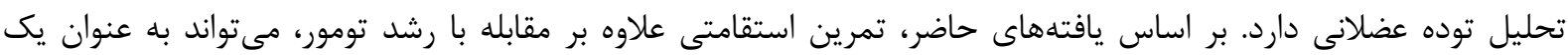

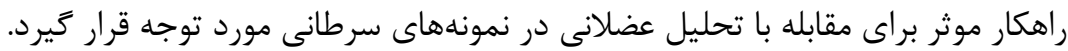

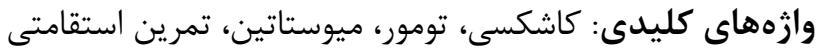


اختلالات مرتبط با تحليل توده عضلانى مطرح و گزارش

شده است كه القاى آنتى ميوستاتين (JA16) در موشهاى جوان و سالم منجر به افزايش قدرت و توده إندان

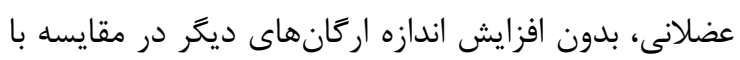
كروه كنترل مى شود (11). يكى از راهكارهايى كه به منظور مقابله و كمك به به درمان

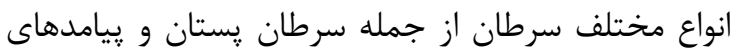

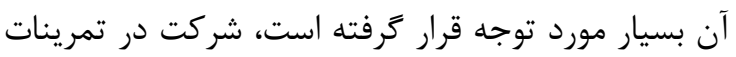
ورزشى است. مطالعات صورت ترفته نشان دادهاند كه

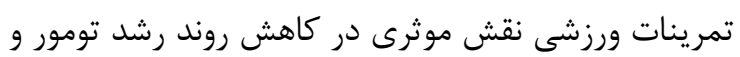

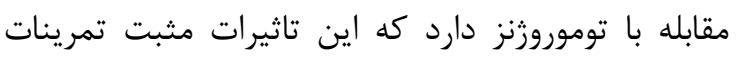

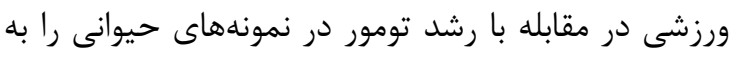

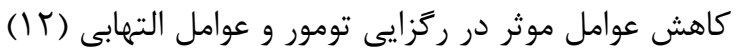

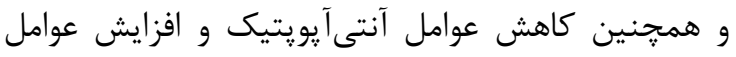
آيويتيك در بافت تومور نسبت دادهاند (با (). باوجود نبود هيج درمان قطعى براى كاشكسى (F) (If)، ثابت

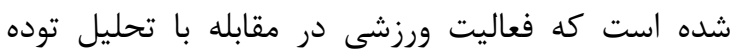
عضلانى ناشى از افزايش سن يا عدم استفاده از عضلات

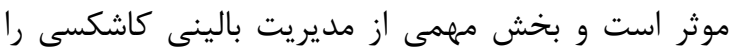

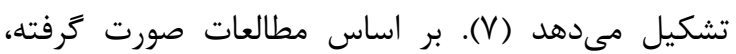

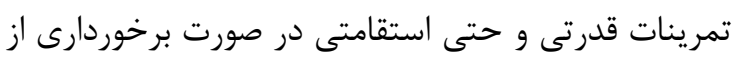

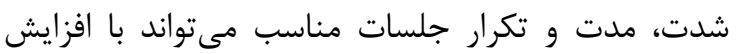

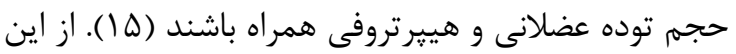

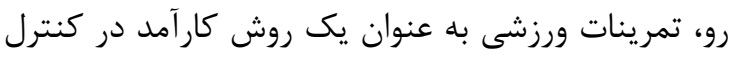

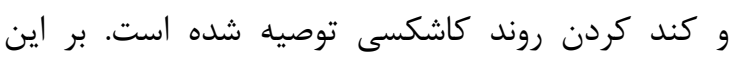

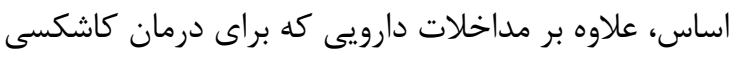

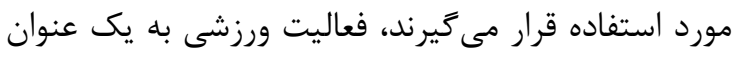

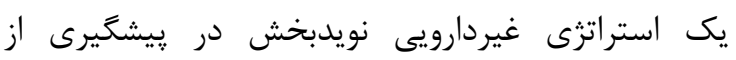
كاشكسى مطرح شده است و با توجه به اينكه در طول كاشكسى، قدرت و استقامتى عضلانى به صورت قابل

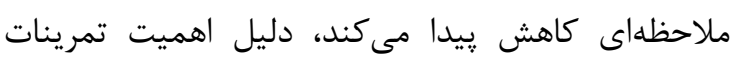

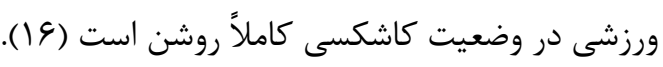
برخى محققان تاثيرات مثبت تمرين ورزشى بر وضعيت كاشكسى را به تنظيم كاهشى ميوستاتين در بافت عضلانى ناني موشهاى مبتلا به سرطان كولون نسبت دادهاند (IV) (IV). علاوه بر كاشكسى، تمرينات ورزشى بسيارى از اثرات

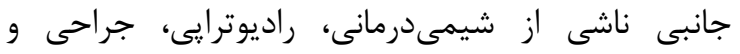

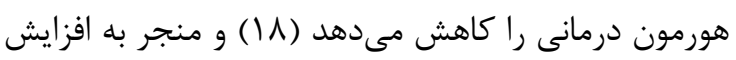

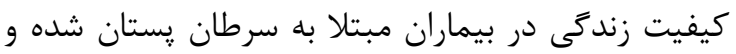

سرطان پِتان شايعترين بدخيمى زنان در سراسر جهان

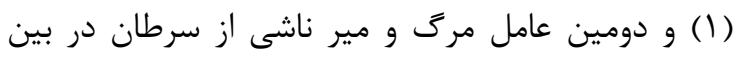

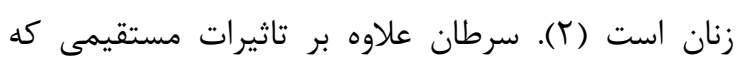
مىتواند بر اندامهاى مختلف بلويزه بافت سرطانى شده

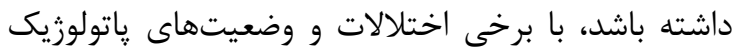

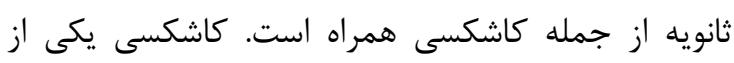
يريامدهاى مخرب مرتبط با انواع مختلف سرطان از جمله سرطان يستان است كه بهواسطه افزايش ميزان متابوليسم

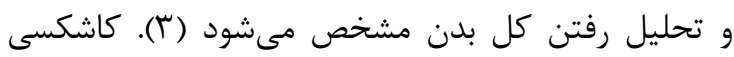
بلهواسطه تحليل ييشرونده عضله اسكلتى (با يا بدون

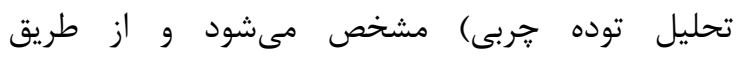

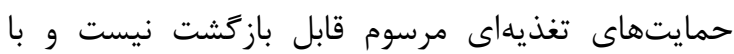

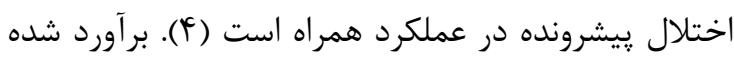

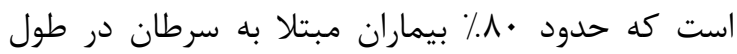

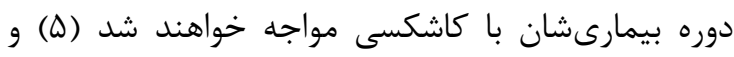

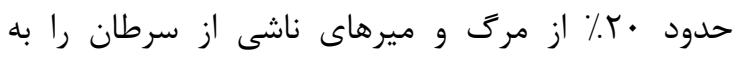
كاشكسى ارتباط دادهاند (9). در وضعيت كاشكسى، كميت و كيفيت عضله اسكلتى

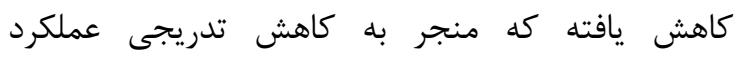

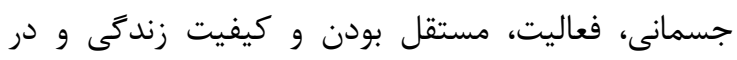
نتيجه عدم تحمل درمانهاى يزشكى (كاهش اثركذارى

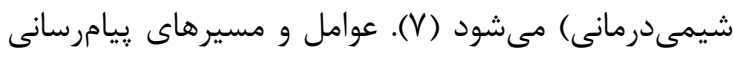

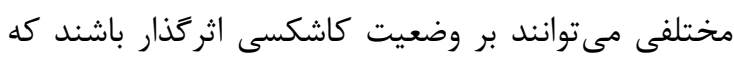
يكى از مهمترين آنها بهواسطه تنظيم افزايشى ميوستاتين

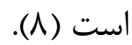

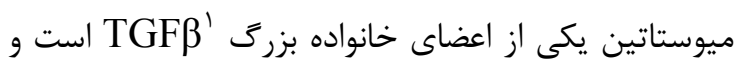
به عنوان يك تنظيم كننده منفى توسعه توده عضله

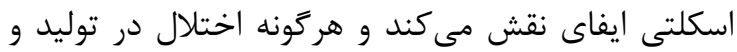

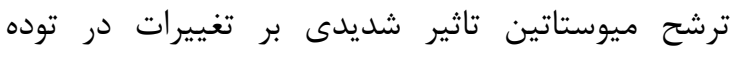

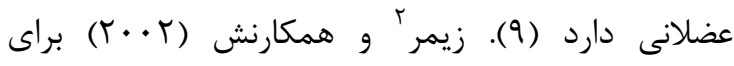

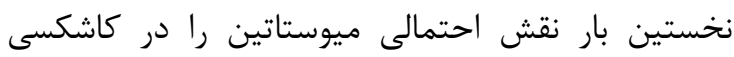

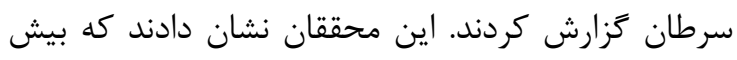

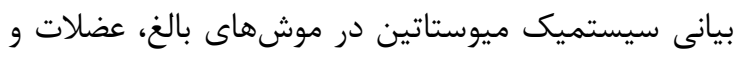
بافت جربى را تحت تاثير قرار داده و اثراتى مشابه بات سندرم كاشكسى در انسان را القا مى كند (•(1). بر اين إنى

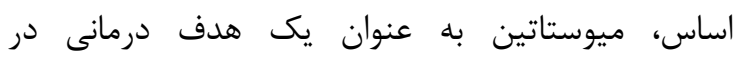

\footnotetext{
${ }^{1}$ Transforming Growth Factor Beta

${ }^{2}$ Zimmers
} 
سرطانى به ميزان مورد نظر ادامه داشت. نهايتاً

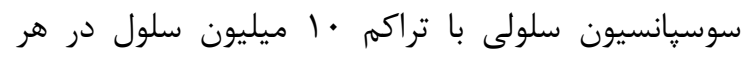

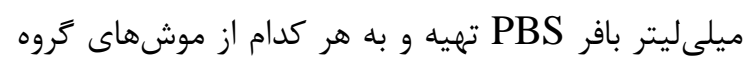

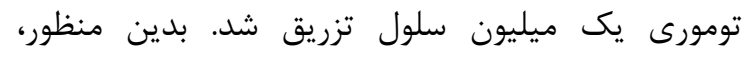

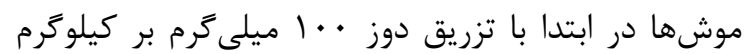

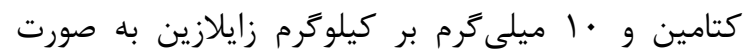

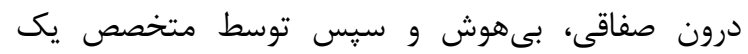

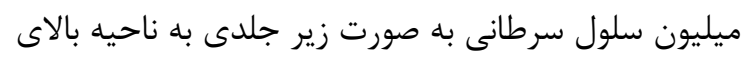
ران سمت راست موشهاى كروه كنترل تومورى و

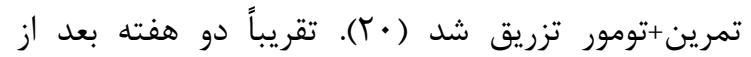
تزريق سلولهاى سرطانى، تومور در ناحيه تزريق شده ترند

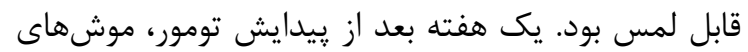

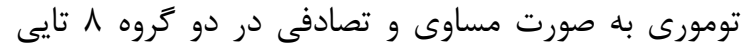
شامل گروه كنترل تومورى و تمرين استقامتى+تومور

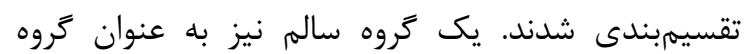
كنترل سالم و مشتمل بر 1 موش در نظر كرفته شد. كروههاى تومورى (كنترل تومورى و تمرين+تومور) و كروه

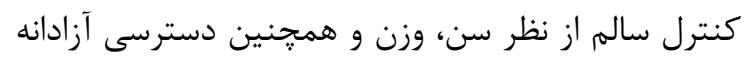

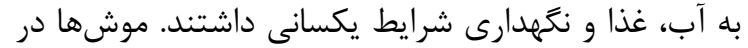
كروههاى كنترل سالم و كنترل تومورى در هيج مداخلهاى

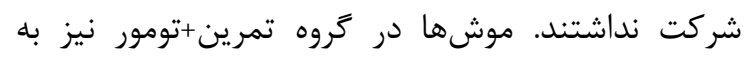
مدت شش هفته در برنامه تمرين استقامتى شركت كردند.

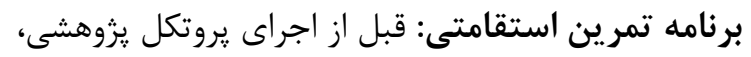

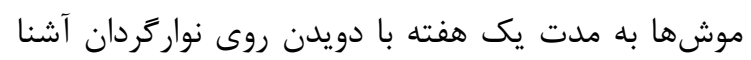

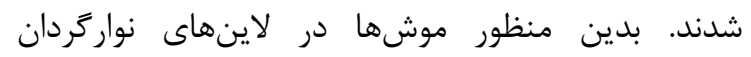
مخصوص جوندكان قرار كرفته و به مدت يك هفته و ورنج جلسه در هفته با سرعت · ا-9 متر بر دقيقه و به مدت فرات

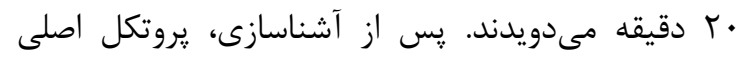

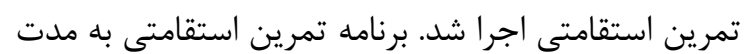
شش هفته و رينج جلسه در هفته (مجموعاً ·r جلسها

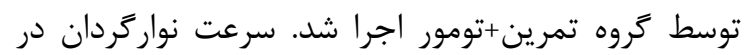

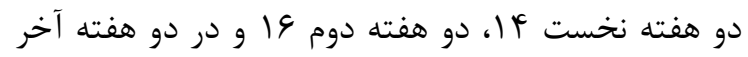

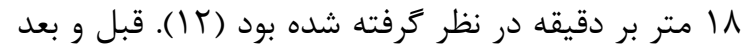

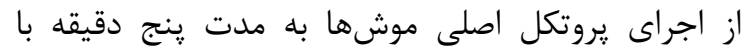

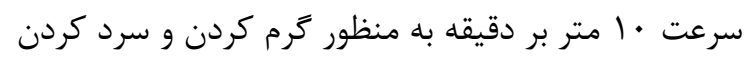

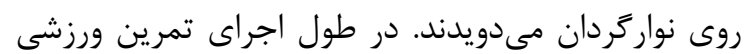
شوك الكتريكى خاموش و از شوك الكتريكى براى تحريك ندي موشها به دويدن استفاده نشد.
خستكى ناشى از سرطان را تقليل مىدهد (19). در

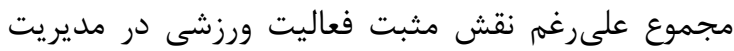
سرطان پستان و بلويزه در جلوگيرى از تحليل توده

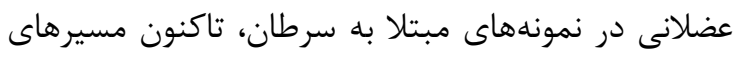
اثركذارى مثبت فعاليت ورزشى تا حدود زيادى ناشناخته مانده است و در يزوهش حاضر براى نخستين بار تغييرات

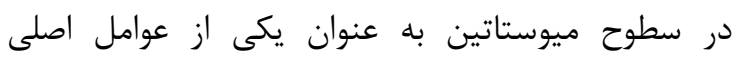
تحريك كننده مسير كاشكسى، در موشهاى مبتلا به به سرطان پֶتان مورد بررسى قرار كرفته است.

\section{مواد و روشها}

تغذيه و نكَهدارى موشهاى مورد بررسى: يزوهش

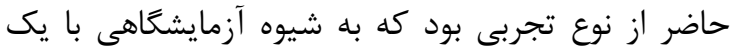

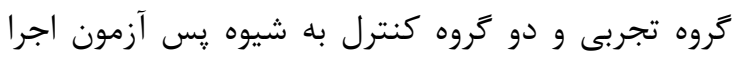

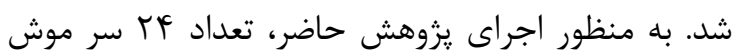

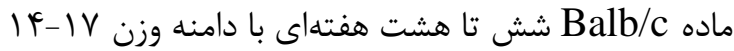
كرم از انستيتوى ياستور تهران خريدارى و به آزائايشكاه

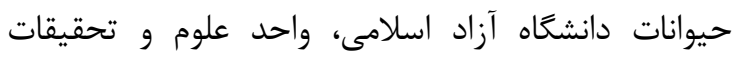

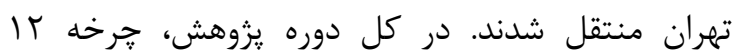
ساعت تاريكى و روشنايى براى تطابق فيزيولوزيك موشها

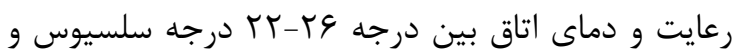

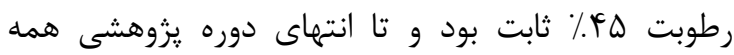
موشهاى به صورت آزادانه به آب و غذاى استاندارد موش دواد دسترسى داشتند. به منظور آشناسازى با محيط، موشها

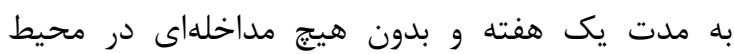

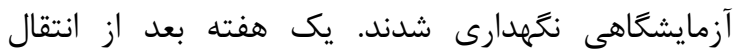

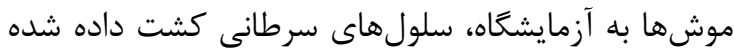

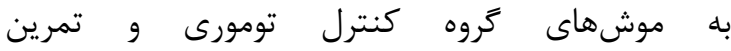
استقامتى+تومور تزريق شدند. لازم به ذكر است كه تمامى مراحل تمرين و اجراى يزوهش مطابق با دستورالعمل مؤسسه سلامت و تغذيه در مورد مراقبت و استفاده از بران حيوانات آزمايشكاهى انجام شد. كشت و تزريق سلولهاى سرطانى: بعد از تهيه رده إناف سلولى كارسينوماى مجارى يستان گيرنده استروزن مثبت از مركز ذخاير زنتيك، سلولها در فلاسك T75 در محيط DMEM با ها 1 ميلىمول بافر HEPES

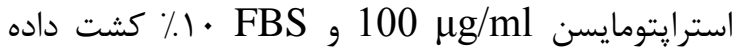
شدند و اين فرآيند تا زمان رسيدن تعداد سلولهاى 
بين گروهى از آزمون آنواى يك راهه و آزمون تعقيبى

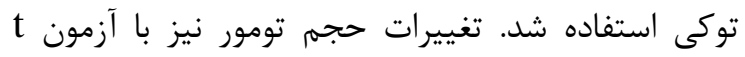
مستقل بررسى شد. تمامى دادهاى حاصل از يزوهش

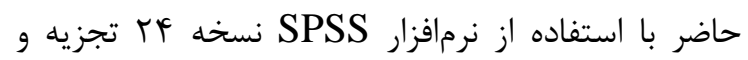

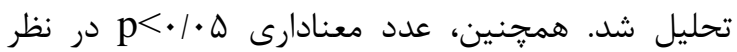
كرفته شد.

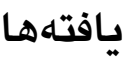

به منظور تجزيه و تحليل دادها، از يافتههاى تمامى

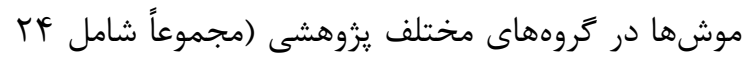

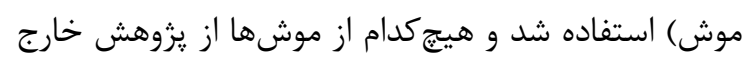

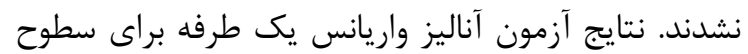
ميوستاتين بافت عضله دوقلو نشان داد كه بين كروهها

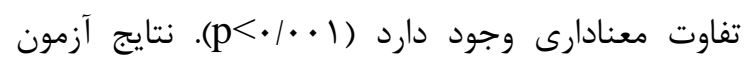
تعقيبى توكى به منظور تعيين محل اختلاف بين كروهها نشان داد كه سطوح ميوستاتين بافت عضله در كروه كنترل سالم به صورت معنادارى كمتر از كروه كنترل

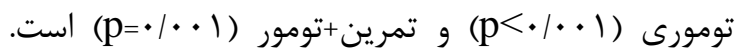
علاوه بر اين، سطوح ميوستاتين عضلانى در كروه ترون تمرين+تومور در مقايسه با كروه كنترل تومورى كاهش إنى

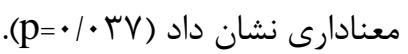

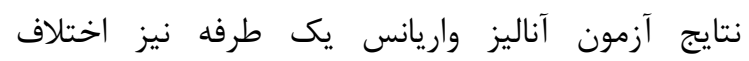
معنادارى را بين وزن عضله دوقلوى گروههاى مختف نشان

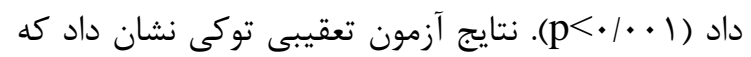

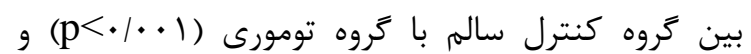

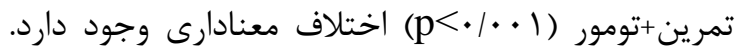
علاوه بر اين، اختلاف بين كروه تمرين+ تومور با كروه

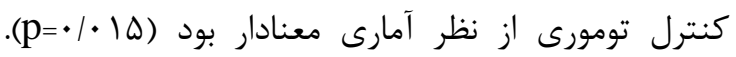

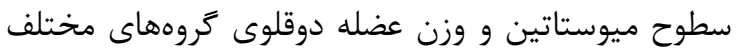
يزوهشى در جدول شماره ا نشان داده شده است. نتايج

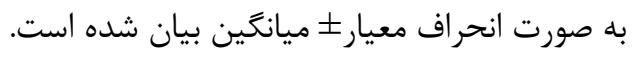

سنجش متغيرهاى مورد بررسى: بس از بيدايش تومور،

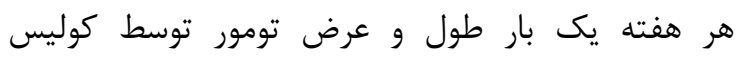

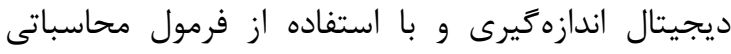

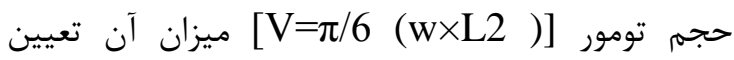

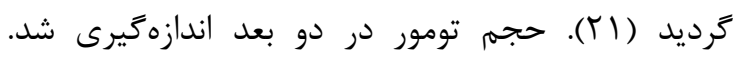

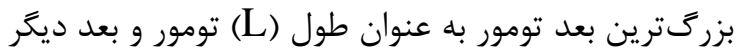

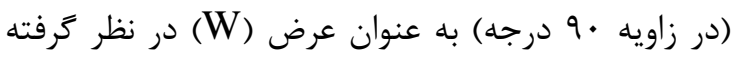
شد. يس از قربانى كردن موشها، بلافاصله بافت عضله درانه

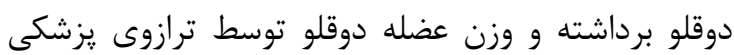

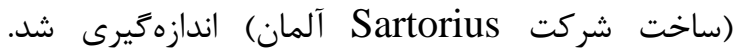
سيس بافت عضلانى در نيتروزن مايع فريز و تا زمان انجام

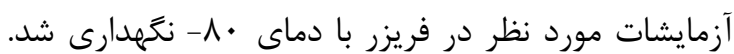

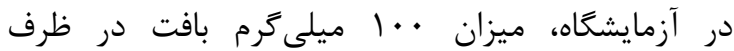
هموزنايزر حاوى محلول ليزات قرار داده شد و بافت كاملاً

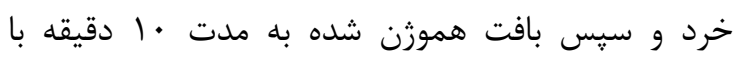
IT... .

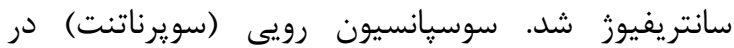
ميكروتيوب جديد منتقل شد. محلول ليزات حاوى روبي PMSF و KH2PO4 Na2HPO4 ، NaCl،KCl (TY)

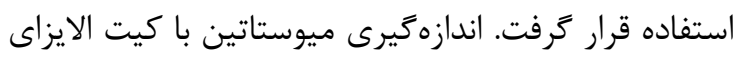

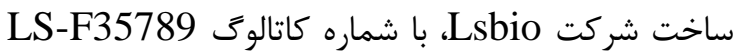
و طبق دستورالعمل شركت سازنده انجام شد. روشهاى آمارى تجزيه و تحليل دادهها: بعد از تجزيه

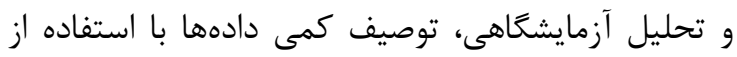

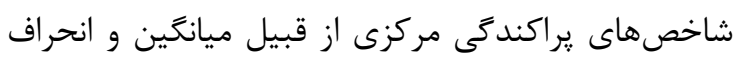

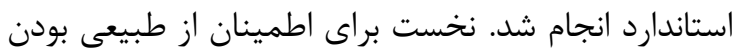

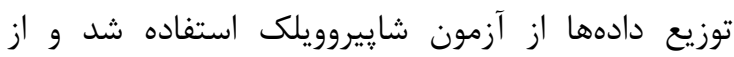

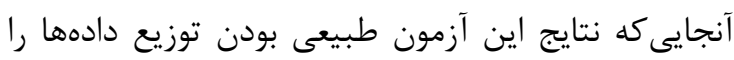

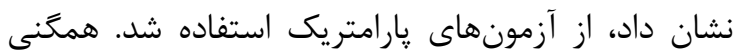
واريانسها با آزمون لون بررسى شد. براى مقايسه تغييرات بارئ

\begin{tabular}{|c|c|c|}
\hline \multicolumn{3}{|c|}{ جدول ا: سطوح ميوستاتين و وزن عضله دوقلو در كروههاى مختلف } \\
\hline عطوح ميوستاتين در بافت دوقلو (pg/ml) & وزن عضله دوقلو (ميلى & كروه \\
\hline$\square r r / I r \pm r / q r$ & $\square \| V / \Lambda \pm r / r q$ & 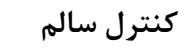 \\
\hline$\Delta \Delta / G Y \pm F / 9 \Lambda$ & $q \cdot \mid \Lambda \vee \pm r / \cdot q$ & كنترل تومورى \\
\hline$\# \Delta \cdot|\Lambda \vee \pm r /| \cdot$ & $\# १ ९ / r \Delta \pm r / 9 r$ & 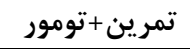 \\
\hline
\end{tabular}

口 نشانه اختلاف معنادار معنادار با كروههاى تومورى (كنترل تومورى، تمرين+تومور)

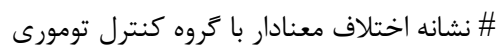




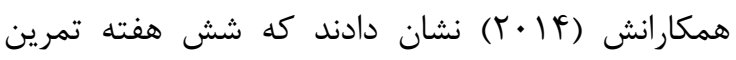
استقامتى در رتهاى يير منجر به كاهش معنادار بيان ميوستاتين و افزايش قدرت و توده عضلانى مىشود كه بر

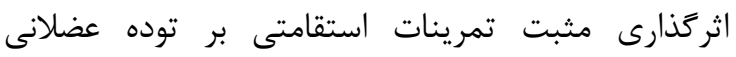

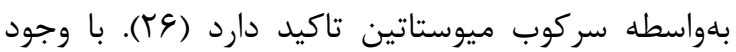
يافتها و نوع و مدت زمان مشابه برنامه تمرينى،

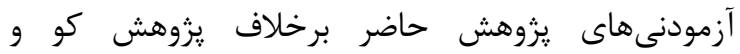

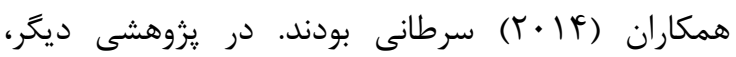

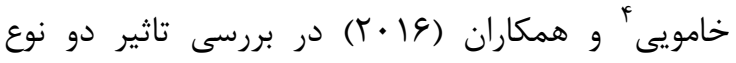
تمرين هوازى و مقاومتى روى وضعيت كاشكسى موشهاى مبتلا به سرطان كولون نشان دادند كه هر دو نوع تمرين ومرين با كاهش سطوح ميوستاتين در عضله دوقلو همراه است كه كاهش ميوستاتين در مقايسه با گروه تومورى كنترل به ميه

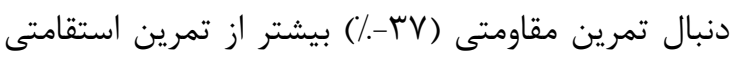

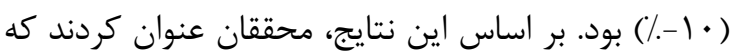
تمرين ورزشى مىتواند يك روش كارآمد به منظور مقابله با كاشكسى سرطان باشد (IV). البته طول دورين دوره تمرين

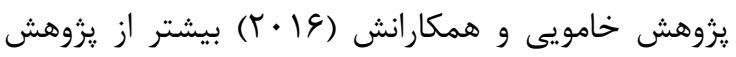
حاضر بود (هشت هفته در مقايسه با شش هفته) و نوع تومور القا شده (تومور كولون در مقايسه با تومور يستان)

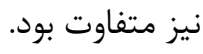
برخى محققان نيز عنوان كردهاند كه برنامه تمرين ورزشى به صورت فعاليت اختيارى روى جرخ كارسنج (9 (19 روز) با افزايش معنادار وزن عضله تيبياليس قدامى در كروه تمرين كرده در مقايسه با گروه كنترل همراه است كه

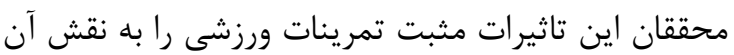

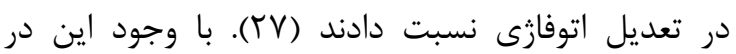
يزوهش حاضر به جاى عضله تيبياليس قدامى، وزن عضله

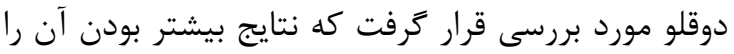

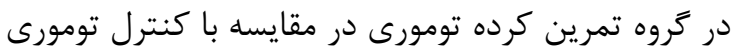

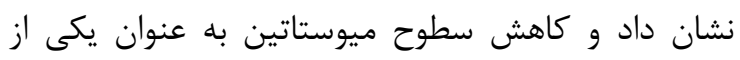
مسيرهاى احتمالى اثرگذارى مثبت تمرينات استقامتى در جلوگيرى از تحليل توده عضلانى مرتبط با كاشكسى مطرح شد. اين يافتهها بر اين واقعيت تاكيد دارد كه انواع مختلف تمرينات ورزشى استقامتى (به صورت اختيارى يا اجبارى) با شدتهاى مختلف مىتواند در كند كردن روند

${ }^{4}$ Khamoui
نتايج آزمون آناليز t مستقل براى حجم تومور نيز نشان داد

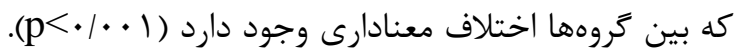
بر مبناى نتايج حاضر، حجم تومور در گروه تمرين+تومور به صورت معنادارى كمتر از گروه كنترل تومورى است. اندازه حجم تومور در جدول شماره r گزارش شده است.

\begin{tabular}{|c|c|}
\hline حجم تومور (سانتىمتر مكعب) & كروه - اه \\
\hline$\cdot|\Lambda| \Delta \pm \cdot / \cdot 9 \Delta$ & كنترل تومورى \\
\hline$\# \cdot / 4 \Delta T \pm \cdot / \cdot 9 V$ & تمرين+تومور \\
\hline
\end{tabular}

بحث

يزوهش حاضر با هدف بررسى تاثير شش هفته تمرين استقامتى بر حجم تومور و سطوح ميوستاتين در بافت عضلانى موشهاى ماده مبتلا به سرطان رِّتان انجام شد.

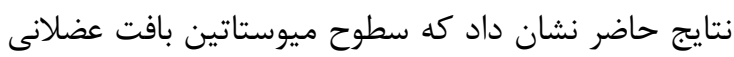
در گروه تمرين+ تومور به صورت معنادارى كمتر از گروه كنترل تومورى بود (WV) دوقلو به صورت معنادارى در زروه تمرين+تومور در برد

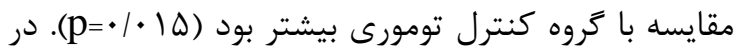

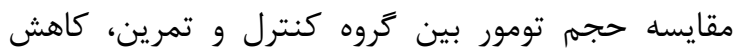
معنادار حجم تومور در زروه تمرين در مقايسه با گروه

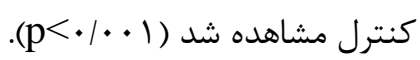
بيان ميوستاتين در برخى وضعيتهاى مرتبط با آتروفى منئه نئن

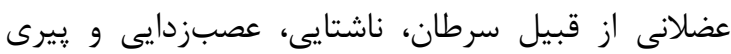
دجار تنظيم افزايشى مىشود (سT). در تاييد اين كفتهانها، نتايج حاضر نيز نشان داد كه سرطان پِّتان با افزايش سطوح ميوستاتين بافت عضلانى در مقايسه با گروه كنترل

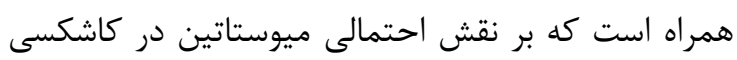
سرطان تاكيد دارد. يافتهاى حاضر نشان دهنده نقش تمرينات ورزشى استقامتى در تنظيمى كاهشى ميوستاتين بافت عضلانى در موشهاى تومورى بود. نتايج در رابطه با تاثير تمرينات ورزشى بر سطوح ميوستاتين ضد و نقيض است و برخى

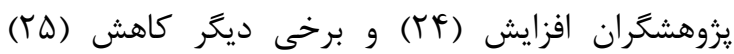

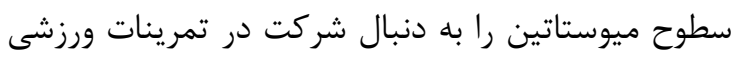

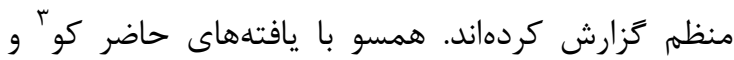

${ }^{3} \mathrm{Ko}$ 
فعاليت ميوستاتين در هيڤرتروفى عضلانى تاكيد دارد

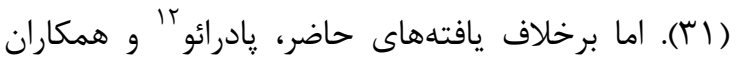

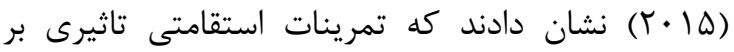
سطوح سرمى ميوستاتين و سطوح آن در بافت قلب رتهاى تومورى شده با N-metil-N-nitrosurea ندارد (Yr). البته نوع آزمودنى (رت در مقايسه با موش)، جايعاه بررسى (قلب و سرم در مقايسه با عضله دوقلو در يثوهش حاضر) و همجنين نوع سلولهاى سرطانى تزريق شده، متفاوت از يروهش حاضر بود كه همه اين موارد مىتواند نتايج متناقض با يزوهش حاضر را توجيه كند. برخى

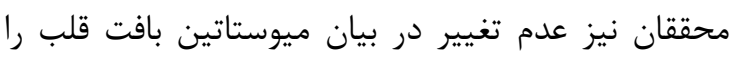
بعد از هشت هفته تمرين مقاومتى در رتهاى سالم ويستار نشان دادهاند (سT). در مجموع، يافتههاى ارايه شده در اين بخش و همجنين نتايج يزوهش حاضر در رابطه با تاثير تمرينات ورزشى بر سطوح ميوستاتين نشان داد كه تغييرات ميوستاتين به دنبال تمرينات ورزشى ممكن است به عوامل مختلفى بستخى داشته باشد كه از جمله آنها مىتوان به طول دوره تمرين ورزشى، شدت، مدت و نوع

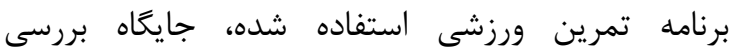
ميوستاتين (سرم، عضله اسكلتى، قلب و...) و همجنين عواملى از قبيل نوع آزمودنىها و تومور القا شده اشاره كرد. احتمالاً روش بررسى تغييرات ميوستاتين (بيان زن، الايزا و...) هم مىتواند بر نتايج متناقض موجود در اين زمينه

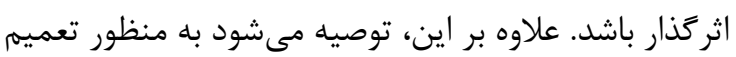
يافتههاى حاضر روى نمونههاى انسانى با احتياط عمل باسل شود و مطالعات بيشترى در اين رابطه مورد نياز است. يكى ديگر از يافتههاى يزوهش حاضر اين بود كه شش مه هفته تمرين استقامتى با كاهش معنادار حجم تومور همراه

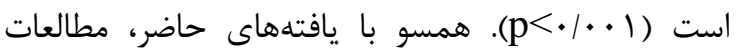
متعددى كاهش حجم تومور را به دنبال انواع مختلف تمرينات ورزشى به صورت استقامتى (T) (I)، مقاومتى (IT)

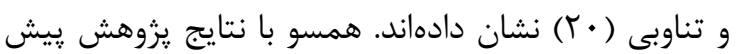
رو، زيلينسكى و همكاران (ץ + . r) نشان دادند كه تمرينات دويدن استقامتى در موشهاى بالب سى موجى مونب كاهش

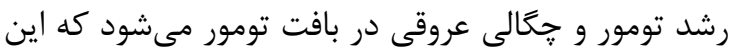
امر را به كاهش تجمع نوتروفيلها و ماكروفازها نسبت وستيت دادند (YY). علاوه بر اين، مسيرهاى ديخرى از قبيل

${ }^{12}$ Padrão
تحليل توده عضلانى ناشى از سرطان در نمونهاى حيوانى مبتلا به سرطان موثر باشد. در مورد سازوكارى كه ميوستاتين مىتواند منجر به موكر به ماند

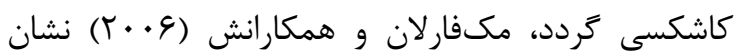
دادند كه درمان با ميوستاتين منجر به تنظيم افزايشى مردى زنهاى مرتبط با يوبى كوئيتين از قبيل atrogin-1 و MuRF-1 ${ }^{\bowtie}$

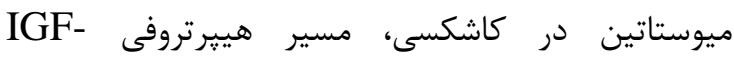

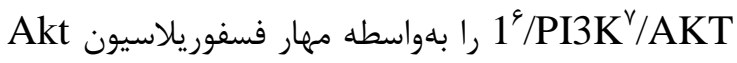
معكوس مى كند و در نتيجه موجب افزايش

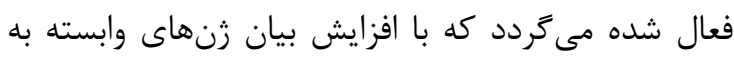

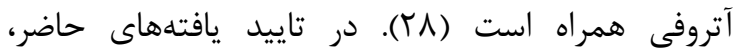

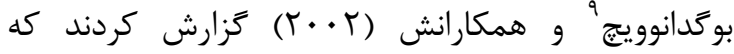
درمان موشها با آنتىبادى ميوستاتين منجر به افزايش

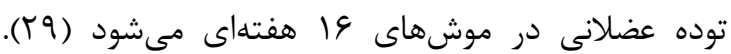

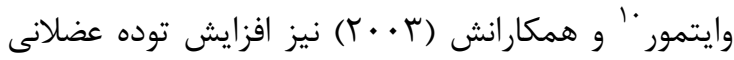
را در موشهاى وب-9 هفتهاى متعاقب تزريق آنتىبادى

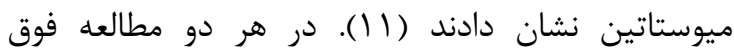

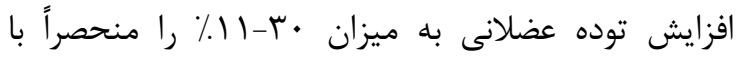

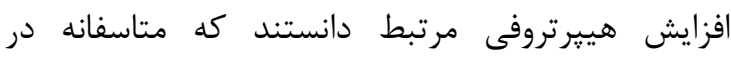

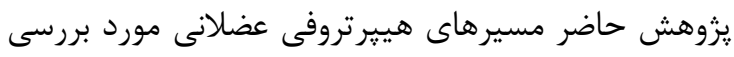

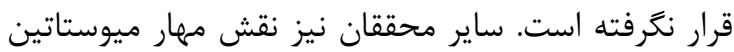
را در رشد عضلانى موشهاى سالم و مبتلا به سرطان

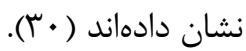
برخى مطالعات صورت گرفته روى نمونههاى انسانى نيز به نقش تمرينات ورزشى (مقاومتى) در كاهش سطوح سرمى مرى ميوستاتين اشاره كردهاند. در اين راستا، صارمى و همكاران

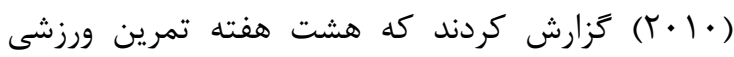
مقاومتى به تنهايى يا در تركيب با مكمل كراتين منجر به كاهش معنادار سطوح سرمى ميوستاتين در مردان جوان

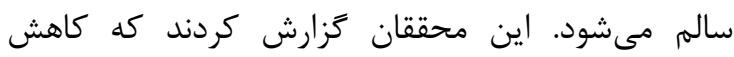
سطوح ميوستاتين سرمى با افزايش معنادار توده خالص مردين بدن ("LBM") همراه بوده است كه بر نقش موثر مهار

\footnotetext{
${ }^{5}$ Muscle RING Finger 1

${ }^{6}$ Insulin-like growth factor 1

${ }^{7}$ Phosphoinositide 3-Kinase

${ }^{8}$ Forkhead Box Protein O1

${ }^{9}$ Bogdanovich

${ }^{10}$ Whittemore

${ }^{11}$ Lean Body Mass
} 
gTOR (Mammalian Target of Rapamycin) IGF-I

$$
\text { غيره نيز تيرداخته شود. }
$$

\section{نتبحه}

از آنجايى كه يكى از مسيرهاى عمده در بروز كاشكسى عضلانى، تنظيمى افزايشى سطوح ميوستاتين به عنوان يك عامل بازدارنده رشد عضلانى است، نتايج يزوهش حاضر

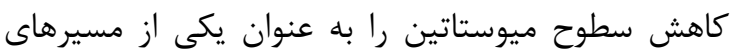
اثرگذارى مثبت تمرين ورزشى بر كاشكسى معرفى مئى مى كند. بر اين اساس، مىتوان عنوان كرد كه تمرينات ورزشى استقامتى علاوه بر كاهش حجم تومور، از طريق استى مهار زنهاى دخيل در آتروغى عضلانى و كاشكسى مىتواند به عنوان يك راهكار كمكى براى مهار تحليل عضلانى مورد توجه قرار گيرد. از اين رو ممكن است شركت در تمرينات استقامتى به منظور مقابله با اثرات تحليل برنده سرطان روى بافت عضلانى بتواند موثر واقع

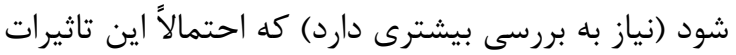

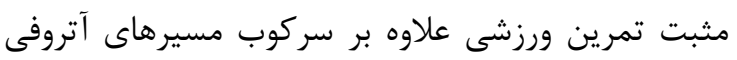
با فعال كردن مسيرهاى هاييرتروفيك نيز مرتبط است كه

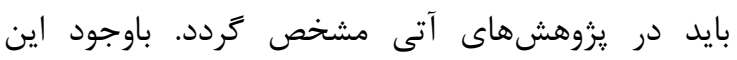

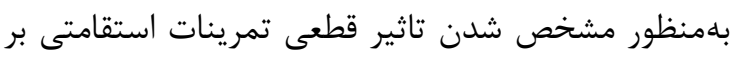
كاشكسى سرطان نياز به انجام مطالعات بيشترى است.

\section{تقدير و تشكر}

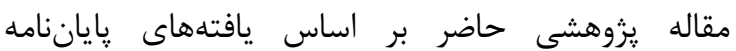
كارشناسى ارشد رشته فيزيولوزى ورزشى نكاشته شده است. بدينوسيله از مسولين دانشكده يِيرايزشكى تهران،

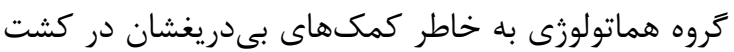
و تزريق سلولهاى سرطانى تشكر مىشود.

\section{تعارض منافح}

نويسندگان اعلام مىدارند كه هيج تعارض منافعى در

$$
\text { يزوهش حاضر وجود ندارد. }
$$

كاهش عوامل التهابى (هـ، عَ)، كاهش عوامل مرتبط با رگزايى تومور (IT) و افزايش عوامل ضدالتهابى (YV) در بافت تومور را به عنوان مسيرهاى احتمالى اثرگذارى تمرين ورزشى در كاهش حجم تومور معرفى كردهاند. البته به نظر مىرسد مدت زمان دوره تمرين ورزشى نيز در تغييرات مشاهده شده در حجم تومور موثر است، به مبه

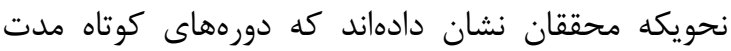
تمرين ورزشى (دو هفته) تغيير معنادارى در حجم تومور ايجاد نمى كند (Y^). جالب اينكه برخى محققان ززارش كردهاند كه ميوستاتين توسط سلولهاى تومورى نيز ترشح مىشود و ميوستاتين ترشح شده از بافت تومور مىتواند نقش مهمى در ياتوزنز كاشكسى سرطان داشته باشد

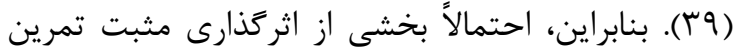
ورزشى بر كاشكسى با كاهش حجم تومور و در نتيجه كاهش ترشح عوامل اثرگذار بر كاشكسى از بـ جمله ميوستاتين مرتبط باشد كه متاسفانه در يزوهش حاضر تغييرات ميوستاتين در بافت تومور بررسى نشده است و به منظور شناسايى مسيرهاى دقيق تاثير تمرين استقامتى بر كاشكسى عضلانى بايد مطالعات بيشترى صورت گيرد. با اين همه، برخى محققان عنوان كردهاند كه احتمالاً ارتباطى بين حجم تومور و كاشكسى وجود ندارد و به نظر

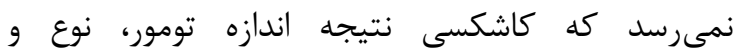

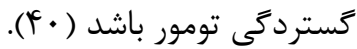
يكى از محدوديتهاى اصلى يزوهش حاضر عدم بررسى تغييرات در توده جربى به عنوان يكى ديگر از بافتهاى متاثر از است كه توصيه مىشود در مطالعات آتى مورد بررسى قرار گيرد. علاوه بر اين، از آنجايى كه در يزوهش

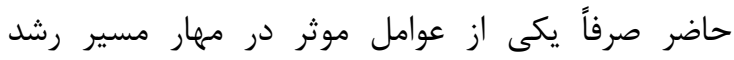
عضلانى (ميوستاتين) مورد بررسى قرار گرفته است و تاثير تمرينات استقامتى بر مسيرهاى هاييرتروفى عضلانى در

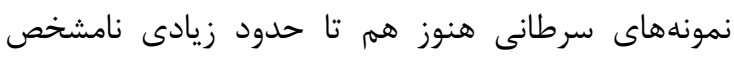
است، توصيه مىشود در يزوهشهاى بعدى به بر برسى هـى تاثير تمرين ورزشى بر عوامل محرك رشد عضلانى از قبيل

the most frequently mutated genes. Oncotarge. 2017; 8(17): 27997-8007.

2. Kaplan MA, Arslan UY, Işıkdogan A, Dane F, Oksuzoglu B, Inanc $M$, et al. 
Biological subtypes and distant relapse pattern in breast cancer patients after curative surgery (Study of anatolian society of medical oncology). Breast Care 2016; 11(4):248-52.

3. Jackman RW, Floro J, Yoshimine R, Zitin $\mathrm{B}$, Eiampikul $\mathrm{M}$, El-Jack $\mathrm{K}$, et al. Continuous Release of Tumor-Derived Factors Improves the Modeling of Cachexia in Muscle Cell Culture. Frontiers in Physiology 2017 25;8:738.

4. Iwata Y, Suzuki N, Ohtake H, Kamauchi $\mathrm{S}$, Hashimoto N, Kiyono T, et al. Cancer cachexia causes skeletal muscle damage via transient receptor potential vanilloid 2- independent mechanisms, unlike muscular dystrophy. Journal of cachexia, sarcopenia and muscle 2016; 7(3):366-76.

5. Bonetto A, Kays JK, Parker VA, Matthews RR, Barreto R, Puppa MJ, et al. Differential bone loss in mouse models of colon cancer cachexia. Frontiers in physiology 2017; 11; 7:679.

6. Ferreira R, Nogueira-Ferreira R, Vitorino $\mathrm{R}$, Santos LL, Moreira-Gonçalves D. The impact of exercise training on adipose tissue remodeling in cancer cachexia. Porto Biomedical Journal 2017; 24(7): 3253-9.

7. Maddocks M, Murton AJ, Wilcock A. Improving muscle mass and function in cachexia: non-drug approaches. Current opinion in supportive and palliative care 2011; 5(4):361-4.

8. Costelli P, Muscaritoli M, Bonetto A, Penna F, Reffo P, Bossola M, et al. Muscle myostatin signalling is enhanced in experimental cancer cachexia. European journal of clinical investigation 2008; 38(7):531-8.

9. 9. Argilés JM, Busquets S, López- Soriano FJ, Costelli P, Penna F. Are there any benefits of exercise training in cancer cachexia? Journal of cachexia, sarcopenia and muscle 2012; 3(2):73-6.

10. Zimmers TA, Davies MV, Koniaris LG, Haynes P, Esquela AF, Tomkinson KN, et al. Induction of cachexia in mice by systemically administered myostatin. Science 2002; 296(5572): 1486-8.
11. Andre MS, Johnson M, Bansal PN, Wellen J, Robertson A, Opsahl A, et al. A mouse anti-myostatin antibody increases muscle mass and improves muscle strength and contractility in the mdx mouse model of Duchenne muscular dystrophy and its humanized equivalent, domagrozumab (PF-06252616), increases muscle volume in cynomolgus monkeys. Skeletal muscle 2017; 7(1):25.

12. Shalamzari SA, Agha-Alinejad $\mathrm{H}$, Alizadeh S, Shahbazi S, Khatib ZK, Kazemi A, et al. The effect of exercise training on the level of tissue IL-6 and vascular endothelial growth factor in breast cancer bearing mice. Iran J Basic Med Sci 2014;17(4): 231-58.

13. Khori V, Shalamzari SA, Isanejad A, Alizadeh AM, Alizadeh S, Khodayari S, et al. Effects of exercise training together with tamoxifen in reducing mammary tumor burden in mice: Possible underlying pathway of miR-21. European journal of pharmacology 2015; 765: 179-87.

14. Fearon K, Strasser F, Anker SD, Bosaeus I, Bruera E, Fainsinger RL, et al. Definition and classification of cancer cachexia: an international consensus. The lancet oncology 2011; 12(5): 489-95.

15. Konopka AR, Harber MP. Skeletal muscle hypertrophy after aerobic exercise training. Exercise and sport sciences reviews 2014; 42(2): 53-61.

16. Bowen TS, Schuler G, Adams V. Skeletal muscle wasting in cachexia and sarcopenia: molecular pathophysiology and impact of exercise training. Journal of cachexia, sarcopenia and muscle 2015; 6(3): 197-207.

17. Khamoui AV, Park BS, Kim DH, Yeh MC, Oh SL, Elam ML, et al. Aerobic and resistance training dependent skeletal muscle plasticity in the colon-26 murine model of cancer cachexia. Metabolism 2016; 65(5): 685-98.

18. Loprinzi PD, Cardinal BJ, WintersStone K, Smit E, Loprinzi CL. Physical activity and the risk of breast cancer recurrence: a literature review. In Oncology nursing forum 2012; 39(3): 26974. 
19. Pinto AC, de Azambuja E. Improving quality of life after breast cancer: dealing with symptoms. Maturitas 2011; 70(4): 343-8.

20. Ahmadian M, Azizbeigi K, Delfan Z, Atashak S. The Effect of High Intensity Interval Training on STAT-3 and Angiopoietin-1 Gene Expression, and tie-2 Protein in Mice with Breast Cancer. Iranian Quarterly Journal of Breast Disease 2018; 11(1):37-46.

21. Jones LW, Viglianti BL, Tashjian JA, Kothadia SM, Keir ST, Freedland SJ, et al. Effect of aerobic exercise on tumor physiology in an animal model of human breast cancer. J Appl Physiol 2010; 108(2): 343-8.

22. Shamsi MM, Chekachak S, Soudi S, Quinn LS, Ranjbar K, Chenari J, et al. Combined effect of aerobic interval training and selenium nanoparticles on expression of IL-15 and IL-10/TNF- $\alpha$ ratio in skeletal muscle of $4 \mathrm{~T} 1$ breast cancer mice with cachexia. Cytokine 2017; 90: 100-8.

23. Smith IJ, Aversa Z, Alamdari N, Petkova V, Hasselgren PO. Sepsis downregulates myostatin mRNA levels without altering myostatin protein levels in skeletal muscle. Journal of cellular biochemistry 2010; 111(4):1059-73.

24. Willoughby DS. Effects of heavy resistance training on myostatin mRNA and protein expression. Medicine and science in sports and exercise 2004; 36(4):574-82.

25. Matsakas A, Bozzo C, Cacciani N, Caliaro F, Reggiani C, Mascarello F, et al. Effect of swimming on myostatin expression in white and red gastrocnemius muscle and in cardiac muscle of rats. Experimental physiology 2006; 91(6):98394.

26. Ko IG, Jeong JW, Kim YH, Jee YS, Kim SE, Kim SH, et al. Aerobic exercise affects myostatin expression in aged rat skeletal muscles: a possibility of antiaging effects of aerobic exercise related with pelvic floor muscle and urethral rhabdosphincter. International neurourology journal 2014; 18(2):77.
27. Pigna E, Berardi E, Aulino P, Rizzuto E, Zampieri S, Carraro U, et al. Aerobic exercise and pharmacological treatments counteract cachexia by modulating autophagy in colon cancer. Scientific Reports 2016; 6:26991.

28. McFarlane C, Plummer E, Thomas M, Hennebry A, Ashby M, Ling N, et al. Myostatin induces cachexia by activating the ubiquitin proteolytic system through an NF- $\kappa B$ - independent, FoxO1- dependent mechanism. Journal of cellular physiology 2006; 209(2):501-14.

29. Latres E, Pangilinan J, Miloscio L, Bauerlein R, Na E, Potocky TB, et al. Myostatin blockade with a fully human monoclonal antibody induces muscle hypertrophy and reverses muscle atrophy in young and aged mice. Skeletal muscl. 2015; 5(1):34.

30. Liu CM, Yang Z, Liu CW, Wang R, Tien P, Dale R, Sun LQ. Myostatin antisense RNA-mediated muscle growth in normal and cancer cachexia mice. Gene therap. 2008; 15(3):155-60.

31. Saremi A, Gharakhanloo R, Sharghi S, Gharaati MR, Larijani B, Omidfar K. Effects of oral creatine and resistance training on serum myostatin and GASP-1. Molecular and cellular endocrinology 2010; 317(1-2): 25-30.

32. Padrão AI, Moreira-Gonçalves D, Oliveira PA, Teixeira C, Faustino-Rocha AI, Helguero L, et al. Endurance training prevents TWEAK but not myostatinmediated cardiac remodelling in cancer cachexia. Archives of biochemistry and biophysics 2015; 567:13-21.

33. Rashidlamir A, Basami M.R, Attarzadeh Hosseini S.R, Hejazi K, Motevalli Anberani. 8 Weeks of Resistance Training Effect on Myostatin Gene Expression of Myocardium in Healthy Male Wistar Rats. Quarterly of the Horizon of Medical Sciences 2016; 22 (2): 111-6.

34. Zielinski MR, Muenchow M, Wallig MA, Horn PL, Woods JA. Exercise delays allogeneic tumor growth and reduces intratumoral inflammation and vascularization. Journal of Applied Physiology 2004; 96(6): 2249-56. 
35. Murphy EA, Davis JM, Barrilleaux TL, McClellan JL, Steiner JL, Carmichael MD, et al. Benefits of exercise training on breast cancer progression and inflammation in C3 (1) SV40Tag mice. Cytokine 2011; 55(2):274-9.

36. Pedersen L, Idorn $\mathrm{M}$, Olofsson $\mathrm{GH}$, Lauenborg B, Nookaew I, Hansen RH, et al. Voluntary running suppresses tumor growth through epinephrine-and IL-6dependent NK cell mobilization and redistribution. Cell metabolism 2016; 23(3): 554-62.

37. Shiri $Y$, Agha- Alinejad $H$, Gharakhanlou R, Amani Shalamzari S, Saei M A. Effect of six weeks endurance training on tumor tissue IL-10 cytokine levels in breast cancer bearing mice.
Iranian Journal of Endocrinology and Metabolism 2014; 16 (3) :205-10.

38. Woods JA, Davis JM, Kohut ML, Ghaffar A, Mayer EP, Pate RR. Effects of exercise on the immune response to cancer. Medicine and science in sports and exercise 1994; 26(9):1109-15.

39. Lokireddy S, Wijesoma IW, Bonala S, Wei M, Sze SK, McFarlane $C$, et al. Myostatin is a novel tumoral factor that induces cancer cachexia. Biochemical Journal 2012; 446(1):23-36.

40. Fox KM, Brooks JM, Gandra SR, Markus R, Chiou CF. Estimation of Cachexia among Cancer Patients Based on Four Definitions. Journal of oncology. 2009; 693458. 